\section{Hjernens struktur og funksjon etter ekstrem prematuritet}

Det er klare forskjeller mellom ekstremt premature og terminbarn når det gjelder hjerneaktivering og kognitiv funksjon, men kun mindre forskjeller i hjernens struktur.

Til tross for den enorme påkjenningen prematur fødsel påfører kroppen og ikke minst hjernen, overlever stadig flere av barna. Dette skyldes både økt kunnskap, bedre utstyr på føde- og nyfødtavdelingene og endret innstilling til hvem som kan reddes. Men hvordan er langtidsutsiktene for dem som overlever det første kritiske året?

I min avhandling har jeg ved hjelp av strukturell og funksjonell MR undersøkt forskjeller i hjernens struktur og funksjon ved 11 års alder hos ekstremt premature (svangerskapsalder $<28$ uker) eller barn med ekstremt lav fødselsvekt $(<1000 \mathrm{~g})$ og hos barn født til termin. Ved den funksjonelle MRundersøkelsen løste barna en oppgave med økende vanskelighetsgrad basert på arbeidshukommelse og selektiv konsentrasjon.

Ekstremt premature barn hadde oftere strukturelle forandringer i hjernen enn veldig premature, og alle premature hadde økt sannsynlighet for forandringer i forhold til terminbarn. Forandringene var hovedsakelig av mild karakter og ble også funnet hos barna født til termin. Funksjonell MR viste signifikant lavere hjerneaktivering prefrontalt, parietalt og i cingulum hos de ekstremt premature i forhold til terminbarna. De hadde også færre riktige svar på oppgaven. Hjerneaktiveringen viste positiv sammenheng med testresultatene, men ikke med barnas skoleprestasjoner.

Resultatene fra studien kan få betydning både for tilrettelegging på skolen og for radiologisk evaluering av ekstremt premature barn.

\section{Silja Torvik Griffiths}

silja.torvik.griffiths@helse-bergen.no

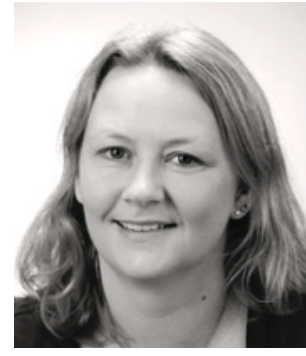

Silja Torvik Griffiths. Foto: Anne Sidsel Herdlevær

Disputas

Silja Torvik Griffiths disputerte for ph.d.-graden ved Universitetet i Bergen 22.11. 2013. Tittelen på avhandlingen er Functional MRI, structural $M R I$ and school performance in extremely preterm/extremely low birth weight children.

\title{
Sammenhengen mellom auramigrene og hjerte- og karsykdom
}

\section{Både genetiske faktorer og tradisjonelle risikofaktorer kan forklare sammenhengen mellom auramigrene og hjerte- og karsykdom.}

Migrene rammer $14 \%$ av befolkningen og er blant lidelsene som bidrar mest til uførhet og sykefravær i samfunnet. I tillegg har personer med auramigrene økt risiko for å utvikle hjerneslag og hjerteinfarkt. Man vet imidlertid lite om mekanismene som ligger bak denne sammenhengen.

I mitt doktorgradsarbeid deltok jeg i gjennomføringen av den hittil største genetiske studien av migrene. Med bidrag fra mer enn 100000 personer med og uten migrene påviste vi 12 genetiske risikoområder for migrene. Disse peker hovedsakelig mot mekanismer i hjernen som er viktige for utviklingen av migrene, men inkluderer også gener som fra tidligere er kjent å medvirke til utvikling av hjerte- og karsykdom.

Ved bruk av data fra Helseundersøkelsen i Nord-Trøndelag fant vi at personer som har migrene med aura ofte utvikler andre risikofaktorer for hjertesykdom over tid, slik som overvekt og ugunstige kolesterolverdier. Dette kan være en av årsakene til den høyere forekomsten av hjerte- og karsykdom i denne gruppen.

Funnene indikerer at migrene og hjerteog karsykdom kan ha delvis felles genetiske årsaker. Betydningen av tradisjonelle risikofaktorer for hjerte- og karsykdom er viktig fordi slike risikofaktorer kan forebygges ved livsstilsendringer eller medisinsk behandling. Det anbefales at personer med auramigrene er ekstra oppmerksomme på å opprettholde en sunn kroppsvekt, fysisk aktivitet og røykeslutt.

Bendik Winsvold bwinsvold@gmail.com

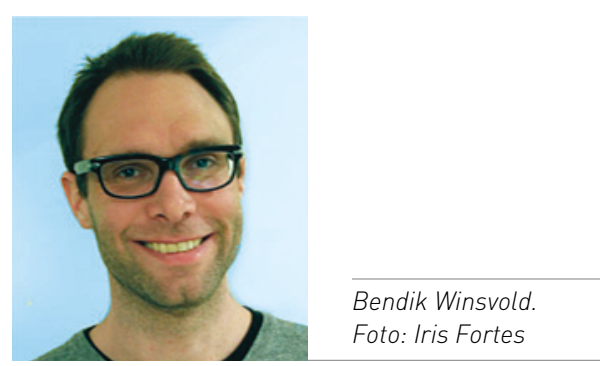

Disputas

Bendik Slagsvold Winsvold disputerte for ph.d.-graden ved Universitetet i Oslo 13.1. 2014. Tittelen på avhandlingen er Migraine and cardiovascular disease. Genetic and epidemiological aspects. 